\title{
Testing the influence of sediment granulometry on heterotrophic respiration with a new laboratory flow-through system
}

\author{
Nataša Mori ${ }^{1}$ (D) $\cdot$ Barbara Debeljak ${ }^{1} \cdot$ David Kocman $^{2} \cdot$ Tatjana Simčič $^{1}$
}

Received: 4 May 2016 / Accepted: 20 November 2016 / Published online: 29 November 2016

(C) The Author(s) 2017. This article is an open access publication

\begin{abstract}
Purpose Increased sedimentation due to land use intensification is increasingly affecting carbon processing in streams and rivers around the globe. This study describes the design of a laboratory-scale flow-through incubation system as a tool for the rapid estimation of sediment respiration. The measurements were compared with those obtained using an in situ closed chamber respiration method. The influence of sediment size on respiration rates was also investigated.

Materials and methods Measurements were conducted on a pre-alpine gravel-bed river sediment separated into the following grain size fractions: $>60 \mathrm{~mm}(14.3 \%), 60-5 \mathrm{~mm}(60.2 \%)$, 5-2 mm (13.7\%), 2-0.063 mm (11.1\%) and $<0.063 \mathrm{~mm}$ $(0.6 \%)$. Concurrently, in situ and laboratory measurements were carried out on a naturally heterogeneous sediment. In situ respiration was determined in closed chambers as $\mathrm{O}_{2}$ consumption over time, while in the laboratory, respiration was determined using flow-through respiration chambers. Oxygen concentrations were measured using a fibre-optic oxygen meter positioned at the inflow and outflow from the chamber. Results and discussion The mean respiration rates within naturally mixed riverbed sediments were $1.27 \pm 0.3 \mathrm{mg} \mathrm{O}$ $\mathrm{dm}^{-3} \mathrm{~h}^{-1}(n=4)$ and $0.77 \pm 0.1 \mathrm{mg} \mathrm{O}_{2} \mathrm{dm}^{-3} \mathrm{~h}^{-1}(n=3)$ for
\end{abstract}

Responsible editor: Jadran Faganeli

The original version of this article was revised: The original article was published electronically on the publisher's internet portal currently SpringerLink) on 29 November 2016 without open access.

\section{Nataša Mori}

natasa.mori@nib.si

1 National Institute of Biology, Večna pot 111, 1000 Ljubljana, Slovenia

2 Institute Jožef Stefan, Jamova 39, 1000 Ljubljana, Slovenia the flow-through chamber system and closed chamber system, respectively. Respiration rates were statistically significantly higher in the flow-through chamber system $(t$ test, $p<0.05)$, indicating that closed chamber measurements underestimated the oxygen consumption within riverbed sediments. Sediment grain size was found to significantly affect respiration rates in both systems (ANOVA, $p<0.001$ ) with the fine sediment fraction (particle size $<0.063 \mathrm{~mm}$ ) having the highest respiration rate $\left(\mathrm{r}_{\text {flow-through }}=51 \pm 23 \mathrm{mg} \mathrm{O}_{2} \mathrm{dm}^{-3} \mathrm{~h}^{-1}\right)$. The smallest fractions $(2-0.063$ and $<0.063 \mathrm{~mm})$, which represent approximately $12 \%$ of total sediment volume, contributed $60 \%$ of total respiration. Conclusions The study demonstrated that flow-through respiration chambers more accurately estimate the respiration rate within riverbed sediments than in situ closed chambers, since the former experiment imitates the natural conditions where continuous interstitial flow occurs in the sediments. We also demonstrated that fine sediments $(<5 \mathrm{~mm})$ substantially contribute to heterotrophic respiration in the studied gravel-bed river.

Keywords Carbon fluxes · Freshwaters · Geomorphology · Hyporheic zone $\cdot$ Respiration $\cdot$ Sediments

\section{Introduction}

Riverbed sediments are biogeochemically active zones playing a key role in the energy flow and carbon processing in running waters (Grimm and Fischer 1984; Findlay 1995; Battin et al. 2016). The surface of riverbed sediments forms only the visible part of a vast continuous area extending beneath and alongside a river bed known as the hyporheic zone (Orghidan 1955). In this three-dimensional zone, where mixing of water, nutrients and organic matter occurs between the surface and subsurface (Boulton et al. 1998), a substantial part of decomposition and nutrient turnover takes place (Naegeli and Uehlinger 1997). 
Here, the interlinked surface and subsurface processes are complex and multidimensional and are driven mainly by hydrological patterns and the geomorphology of the riverbed and adjacent aquifer (Valett et al. 1996; Mermillod-Blondin et al. 2000, 2014). From this aspect, hydrogeomorphological characteristics serve as a structural template that shapes the ecological processes in the hyporheic zone and modes of interaction with surface and ground water. River hydromorphology has been recognized by river managers as an important element of surface waters affecting biological components, such as fish and the benthic invertebrate habitat (Commission of the European Communities 2000), but not as an important driver of key functions, such as organic matter decomposition and nutrient transformation. Moreover, the accumulation of fine sediments on the riverbed surface and within the hyporheic zone is known to have deteriorated effects on carbon fluxes within riverbed sediments and is increasingly enhanced by human pressures such as forestry and agriculture (Hancock 2002; Crawford and Stanley 2016). In order for it to be implemented in river management, more indepth knowledge is needed on the functioning of river ecosystems in relation to hydrogeomorphology and increased sedimentation (Elosegi et al., 2010).

The cycling of carbon, nutrients and pollutants in river sediments is linked to the activity and functional capabilities of the resident microbial communities, which are predominantly in the form of a biofilm covering the available substrate (Battin et al. 2016). Invertebrates that inhabit the interstitial spaces contribute mostly to particulate organic matter processing and the top-down control of microorganisms (Foulquier et al. 2010). The heterotrophic respiration of both biofilm and invertebrates is one of the key processes in lotic ecosystems (Naegeli and Uehlinger 1997; Pusch et al. 1998) and, as such, is one of the most frequently measured functional ecosystem parameters. Mechanistically, aerobic respiration is the biotic conversion of organic carbon to carbon dioxide (YvonDurocher et al. 2012). In an ecosystem, the respiration rate indicates the patterns of carbon fluxes whereas aerobic respiration is expressed as either oxygen consumption or carbon dioxide production (Lampert 1984; Boyd, 1995).

Several methods for measuring oxygen consumption within riverbed sediments have been developed for determining respiration including in situ and laboratory-based closed and continuous-flow chambers. The majority estimate oxygen consumption above the sediment-water interface and do not consider the flow of water through the sediment (e.g. Bowman and Delfino 1980; Jeppesen 1982; Prahl et al. 1991; Jones et al. 1995; Naegeli and Uehlinger 1997; Doering et al. 2011; Ruegg et al. 2015; Simčič et al. 2015). Pusch and Schwoerbel (1994) have developed a portable device with recirculating water to simulate unidirectional flow of water through a quasi-natural sediment sample, enabling them to measure hyporheic community respiration in the field. Uzarski et al. (2001) improved this approach by developing an in situ open system flow- through sediment chambers that included hyporheic zone respiration. Meanwhile, in the laboratory, Mermillod-Blondin et al. (2005) applied gravel-sand filtration columns, modified from those developed by Danielopol and Niederreiter and used by Griebler (1996), to measure biogeochemical transformations, oxygen consumption and microbial activity in hyporheic sediments. Each of these techniques has its limitations, often raising concerns regarding metabolic approximations on a reach or whole stream scale (Uzarski et al. 2004). Despite this, laboratory experiments on a small scale, i.e. in microcosms, in heterogeneous sediments and under realistic interstitial flow conditions, are a promising tool for measuring biogeochemical processes (Mermillod-Blondin et al. 2005). Unfortunately, such studies, with a few exceptions (e.g. Mermillod-Blondin et al. 2005), are lacking.

Hence, the objectives of this study was to test the applicability of a newly designed laboratory flow-through respiration chamber that mimics the interstitial flow through the sediment and where the temperature and other biologically important variables such as oxygen concentrations, nutrients and flow velocity are easy to manipulate. Following the work of Pusch and Schwoerbel (1994), the system used in this study was designed to be used in the laboratory, where different research questions can be addressed under controlled conditions. It differs from gravel-sand filter columns (Mermillod-Blondin et al. 2005), since the interstitial flow velocities and the incubation temperature can be modified and controlled. Respiration measurements obtained using this newly designed system were compared with an in situ closed chamber system, which is proven as an efficient tool for estimating heterotrophic respiration in stream sediments (Naegeli and Uehlinger 1997; Uehlinger et al. 2002; Doering et al. 2011). Finally, already known relationship between sediment granulometry and heterotrophic respiration rates (e.g. Doering et al. 2011; Bodmer et al., 2016) was tested using the new flow-through chamber in order to underline the importance of stream channel geomorphology to the flux of carbon in riverbed sediments.

\section{Material and methods}

Sediment samples were collected on 5 May 2015 from the Kamniška Bistrica River along the downstream reach located near the confluence with the Sava River $\left(46^{\circ} 04^{\prime} 34.08^{\prime \prime} \mathrm{S}\right.$; $14^{\circ} 38^{\prime} 11.09^{\prime \prime} \mathrm{N}, 264 \mathrm{~m}$ a.s.1.). Nine subsamples of sediments (three transversal transects with three samples) were taken from the river channel to account for any riverbed heterogeneity (Fig. 1). A PVC tube $(30 \mathrm{~cm}$ in diameter and $60 \mathrm{~cm}$ in height) was placed into the wetted river channel (water levels from 30 to $40 \mathrm{~cm}$ ) and held there by the hand. The sediment was then collected from the bottom ( $20 \mathrm{~cm}$ of depth layer) of the sampling tube. Using this approach, sediment loss due to water flow was prevented. Part of the naturally heterogeneous 
Fig. 1 Study area and sampling design

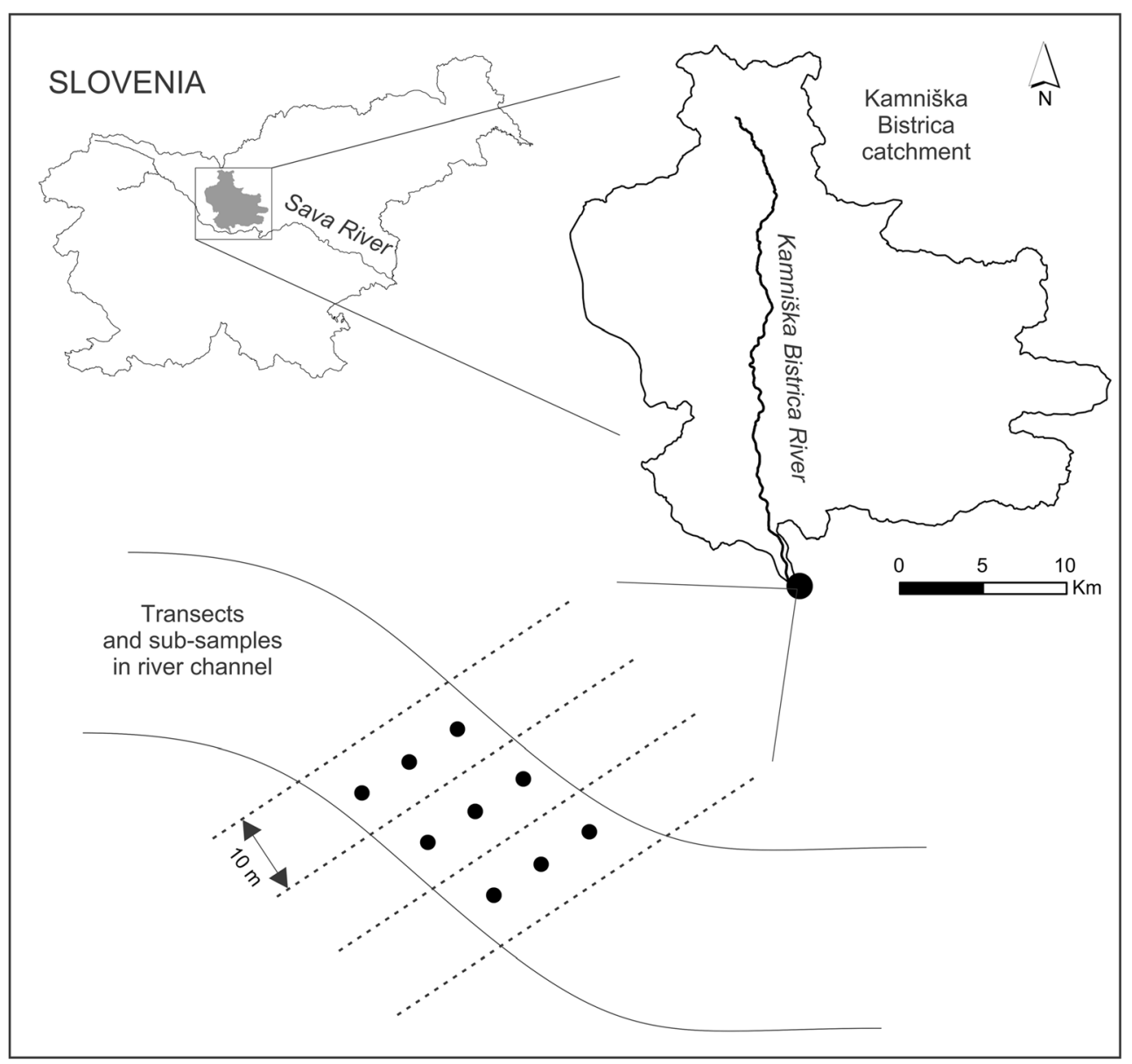

(mixed) sediment was stored for respiration measurements (in situ and in the laboratory). The sediment sample was then fractionated into five grain-size classes $(>60,60-5,5-2,2-$ $0.063,<0.063 \mathrm{~mm}$ ) using a series of stainless steel sieves (Endecotts, London, England). Benthic organisms (e.g. Chironomidae, Nematoda and Oligochaeta) occasionally present in the sediments were removed from the sample. A portion of the sieved sediment fractions were then used for in situ respiration measurements in closed chambers while a portion was transported to the laboratory for flow-through respiration measurements.

In situ respiration was measured in closed chambers as $\mathrm{O}_{2}$ consumption over time (Uehlinger et al. 2002). The mixed and sieved sediment was gently placed into a series of Plexiglas tubes (32 cm long, $5.2 \mathrm{~cm}$ in diameter). Afterward, the tubes were half-filled with sediment and then filled to the top with surface water collected from the sampling site and sealed with rubber stoppers. The tubes were then incubated in situ by burying them into the sediment at the sampling site for approximately $2 \mathrm{~h}$. Each sediment fraction was incubated in triplicate and controls, i.e. tubes filled with water but without the sediment were incubated in the same way. The incubation time was experimentally determined prior to the measurements. During the shorter incubation times $(<1 \mathrm{~h})$, oxygen consumption was below the limits of detection. The tubes were incubated in the dark to avoid formation of artefacts (i.e. photosynthetic activity) and to prevent loss due to strong currents. The oxygen levels were measured using an optical dissolved oxygen sensor (FDO® 925) connected to a WTW Multi 3430 set instrument. Based on the oxygen consumption in the tube $\left(\mathrm{r}, \mathrm{g} \mathrm{O}_{2} \mathrm{~h}^{-1}\right)$, the respiration per sediment volume ( $\mathrm{R}, \mathrm{g} \mathrm{O}_{2} \mathrm{~m}^{-3} \mathrm{~h}^{-1}$ ) was calculated (after Lampert 1984).

In the laboratory, respiration was measured using flowthrough respiration chambers $(\mathrm{V}=0.7 \mathrm{~L})$ with internal and external water flow (Fig. 2). The chambers were filled with $\sim 600 \mathrm{~mL}$ of sediments. The internal water flow through the sediments was maintained using a peristaltic pump (ISM404B, ISMATEC, Wertheim, Germany) with a pump

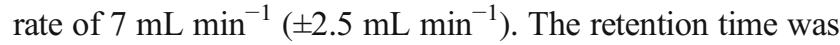
sufficient to produce a difference of $10 \%$ in the $\mathrm{O}_{2}$ concentration between the inlet and outlet water (Prahl et al. 1991). The flow rate applied in the experiment resulted in flow velocities similar to the interstitial flow velocities of gravel-bed rivers, similar to the river surveyed in this study (Wagner and Bretschko 2002). A constant temperature of $15 \pm 0.5^{\circ} \mathrm{C}$ was maintained by water circulating water through the thermal jacket surrounding the chambers. The temperature was the same as the temperature during closed chamber respiration 
Fig. 2 Schematic presentation of flow-through incubation system (a) and a photograph of the incubator and oxymeter (b)

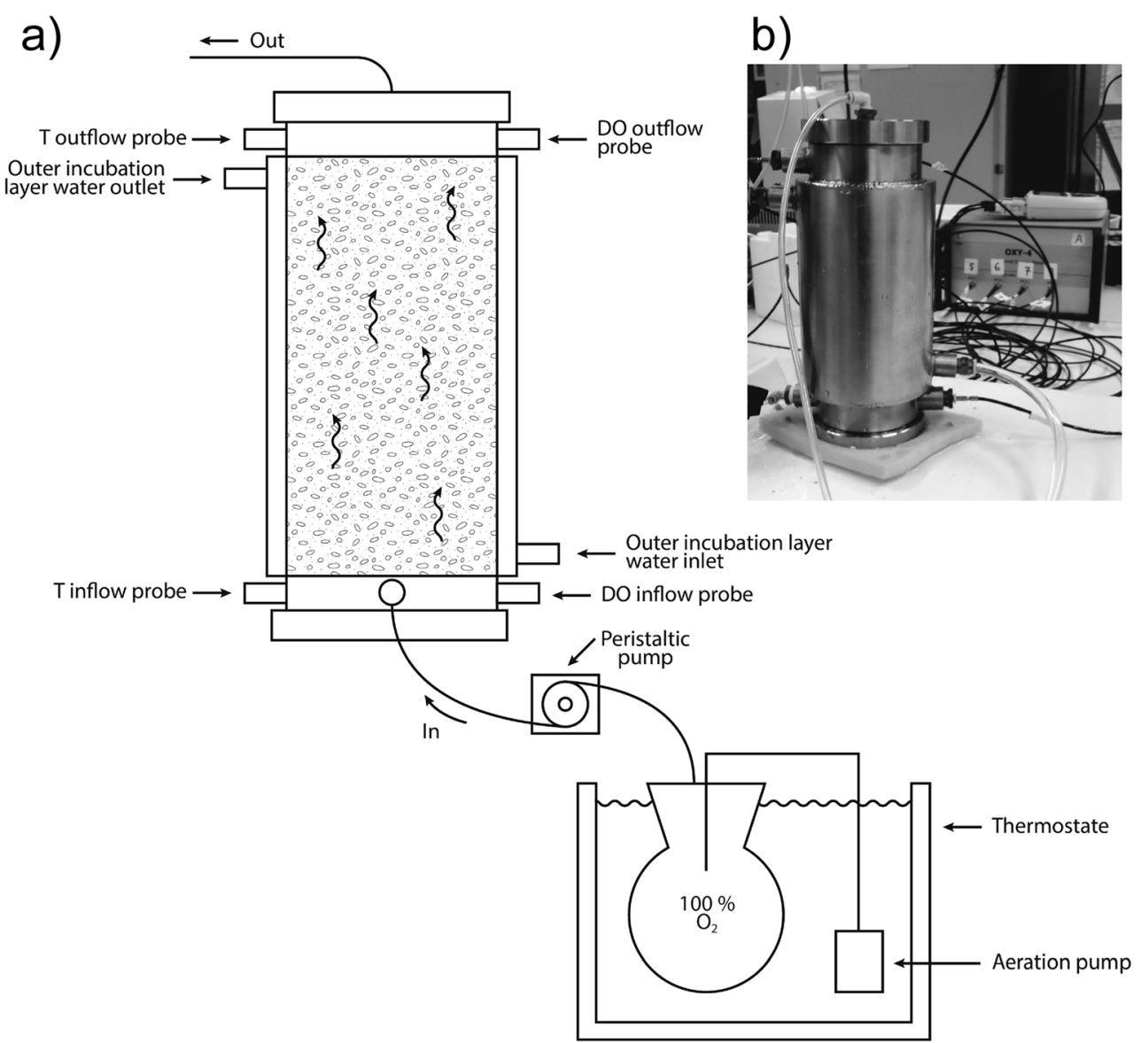

measurements in the field. The inflow water was aerated to maintain $\mathrm{O}_{2}$ concentration close to $100 \%$ saturation. The oxygen concentrations were measured using an fibre-optic oxygen meter (OXY-4, PreSens, Regensburg, Germany) at the inflow and outflow from the inner chamber. The oxygen consumption in the chamber ( $\mathrm{r}, \mathrm{mg} \mathrm{O}_{2} \mathrm{dm}^{-3} \mathrm{~h}^{-1}$ ) was calculated as follows:

$r=\frac{\left(O_{2 \text { in }}-O_{2 \text { out }}\right) f-O_{2 \text { control }}}{\text { Vsed }}$

where $\mathrm{O}_{2 \text { in }}$ and $\mathrm{O}_{2}$ out are oxygen concentrations of water ( $\mathrm{mg} \mathrm{O} \mathrm{O}_{2} \mathrm{~L}^{-1}$ ) at inflow and outflow, respectively; $f$ is the chamber through-flow $\left(\mathrm{L} \mathrm{h}^{-1}\right) ; \mathrm{O}_{2 \text { control }}$ represents oxygen consumption in the controls $\left(\mathrm{mg} \mathrm{O}_{2} \mathrm{~h}^{-1}\right)$ and $\mathrm{V}_{\text {sed }}$ is volume of the sediment $\left(\mathrm{dm}^{-3}\right)$ (after Lampert 1984). Respiration measurements were performed for $1 \mathrm{~h}$. Prior to the experiment, the flow-through system was running for $8 \mathrm{~h}$ to observe the response of respiration over the incubation time. Four replicate measurements were obtained for both the naturally heterogeneous sediment and for each sediment fraction. Control measurements (no sediment) were also performed.

Chemical analyses of the water used for the flow-through experiment were made in two replicates to assess the biogeochemical processes occurring in the sediments. Nutrients $\left(\mathrm{NH}_{4}{ }^{+}, \mathrm{NO}_{3}{ }^{-}, \mathrm{NO}_{2}{ }^{-}\right)$were measured in the inflow and outflow water using ion chromatography (761 Compact IC, Metrohm AG, Herisau, Switzerland) with a precision of $\pm 2 \%$. Detection limits were $0.035 \mathrm{mg} \mathrm{L}^{-1}$ for cations and $0.01 \mathrm{mg} \mathrm{L}^{-1}$ for anions.

A $t$ test was applied to determine if respiration rates within naturally heterogeneous (mixed) sediment in closed and flow-through chambers were significantly different from each other. A two-way analysis of variance (ANOVA) with the type of measurement (closed or flow-through chamber) and sediment size class ( $>60$, $60-5,5-2,2-0.063,<0.063 \mathrm{~mm}$ ) as independent variables and respiration as response variable was conducted to examine the effect of measurement method and sediment size class on respiration rates. The respiration data were tested for normality prior to both analyses ( $t$ test, ANOVA) and were log transformed prior to two-way ANOVA to fit the normality assumptions better.

To estimate patterns of carbon fluxes in relation to sediment granulometry, a conversion factor of 0.38 and respiratory coefficient of 0.85 (Dilly 2001) was used to convert the amounts of consumed oxygen $\left(\mathrm{mg} \mathrm{O}_{2}\right.$ $\mathrm{dm}^{-3} \mathrm{~h}^{-1}$ ) into amounts of carbon processed during respiration (mg C dm ${ }^{-3} \mathrm{~h}^{-1}$ ) (after Lampert 1984). 


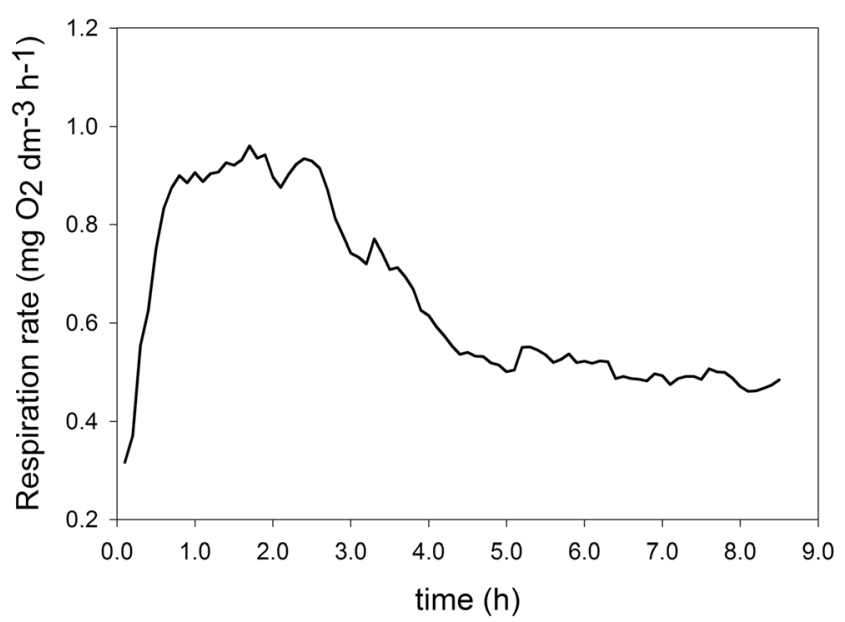

Fig. 3 Respiration rates of natural (mixed) riverbed sediments measured continuously for $8.5 \mathrm{~h}$ with the flow-through system

\section{Results}

When observing the change in respiration rates over the time, the respiration rate of the natural (mixed) sediments reached the highest value $\left(0.9 \mathrm{mg} \mathrm{O}_{2} \mathrm{dm}^{-3} \mathrm{~h}^{-1}\right)$ in approximately 30 min after beginning the measurements in the flowthrough system (Fig. 3). After two hours, the respiration rate decreased steeply and after five hours reached $0.5 \mathrm{mg} \mathrm{O}$ $\mathrm{dm}^{-3} \mathrm{~h}^{-1}$. The rate then stayed constant until the end of the measurements $(3.5 \mathrm{~h})$. An increase in nitrite and nitrate and decrease in ammonium was observed at the outflow (Fig. 4).

The mean respiration rates of natural (mixed) riverbed sediments were $0.77 \pm 0.1 \mathrm{mg} \mathrm{O}_{2} \mathrm{dm}^{-3} \mathrm{~h}^{-1}$ when measured in the closed chamber system and $1.27 \pm 0.3 \mathrm{mg} \mathrm{O}_{2} \mathrm{dm}^{-3} \mathrm{~h}^{-1}$ for the flow-through system (Fig. 5) and were statistically significantly higher in the latter $(t$ test, $p<0.05$ ). When comparing the respiration rates of different sediment size classes $(60-5,5-2$, $2-0.063,<0.063 \mathrm{~mm}$ ), the highest mean respiration rate was observed for the smallest size class $(<0.063 \mathrm{~mm})$ and was
$51 \pm 23 \mathrm{mg} \mathrm{O}_{2} \mathrm{dm}^{-3} \mathrm{~h}^{-1}$ for the flow-through system and $3.8 \pm 0.7 \mathrm{mg} \mathrm{O}_{2} \mathrm{dm}^{-3} \mathrm{~h}^{-1}$ for the closed chamber system. The lowest respiration rates were measured for the largest size class $(60-5 \mathrm{~mm})$ and were $0.27 \pm 0.1$ and $0.27 \pm 0.1 \mathrm{mg} \mathrm{O} 2$ $\mathrm{dm}^{-3} \mathrm{~h}^{-1}$ for the flow-through and closed chamber system, respectively. There was also a statistically significant interaction between the effects of measurement and sediment size class on respiration rate (two-way ANOVA, F (2, $27)=169.09, p<0.001)$. Simple main effects analysis showed that respiration rates were significantly higher during measurements in the flow-through incubation system for the sediment classes $<0.063,2-0.063$, and $5-2 \mathrm{~mm}(p<0.01)$, but there was no significant difference between the two methods in terms of respiration rates for the sediment class of $60-5 \mathrm{~mm}$ $(p=0.927)$. During incubation, an increase in nitrite and nitrate and a decrease in ammonium were observed in the outflow water for all the sediment fractions (Fig. 6). The carbon turnover in the flow-through system was $0.41 \pm 0.09 \mathrm{mg} \mathrm{C}$ $\mathrm{dm}^{-3} \mathrm{~h}^{-1}$ or $97.3 \pm 21.7 \mathrm{mg} \mathrm{C} \mathrm{m}^{-2}$ day $^{-1}$ for naturally heterogeneous sediments (Table 1). The carbon turnover exponentially increased with a decrease in sediment particle size.

The studied riverbed sediments were composed predominantly of sediment size class $60-5 \mathrm{~mm}(60.2 \%)$ with the fine particles $(<0.063 \mathrm{~mm})$ contributing $0.6 \%$ to the total amount of sediment (Fig. 7). The calculated contribution of respiration rates to total respiration were $11.5 \%$ for size class $60-5 \mathrm{~mm}, 28.7 \%$ for size class $5-2 \mathrm{~mm}, 38 \%$ for size class $2-0.063 \mathrm{~mm}$ and $21.9 \%$ for size class $<0.063 \mathrm{~mm}$ (Fig. 6). Over $60 \%$ of total respiration takes place on the sediments with a grain size of $2 \mathrm{~mm}$ or less.

\section{Discussion}

The experimental flow-through system that we designed allowed us to quantify the heterotrophic respiration and
Fig. 4 Nitrite, nitrate, ammonium and oxygen concentrations measured in the inflow water $(n=2)$ and in the outflow water $(n=2)$ after $2 \mathrm{~h}$ and at the end of the measurement

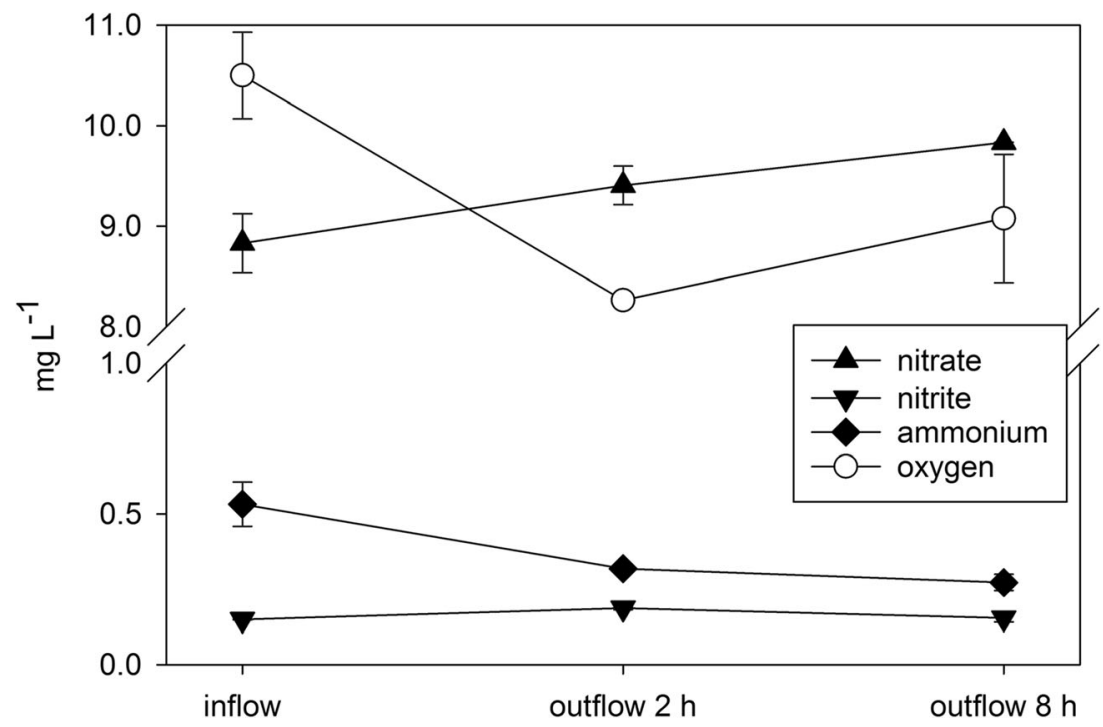




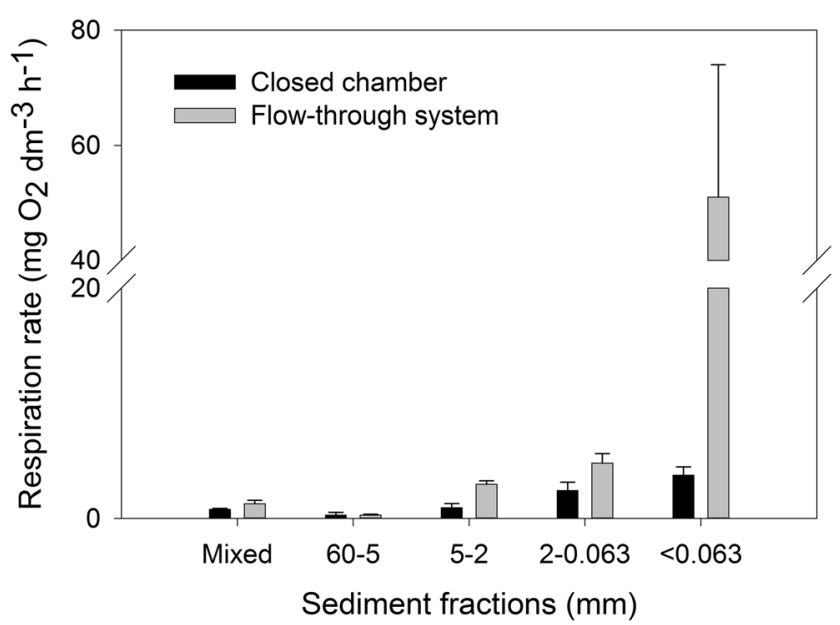

Fig. 5 Respiration rates measured on natural (mixed) riverbed sediments and selected sediment fractions in the closed chamber and flow-through systems

biogeochemical processes in riverbed sediments that are mediated by microorganisms. In comparison to in situ closed chamber measurements, the respiration rates are significantly higher in the newly designed flow-through system. This system imitates the interstitial flow in riverbed sediments and hence presumably provides estimates of respiration rates and nutrient transformations that are more realistic. Similarly, Uzarski et al. (2001, 2004) showed that the flow-through chambers more accurately represent the total system metabolism than do closed chambers. In closed chambers, it is possible to underestimate metabolism because of the limited exchange between interstitial and surface water within the chambers (Grimm and Fisher 1984; Uzarski et al. 2004). For example, Simčič and Mori (2007) demonstrated higher metabolic rates, measured as respiratory potential, in riverbed sediments that more intensively exchange surface and subsurface water, than in the gravel bar sediments where this exchange is less intense. The interstitial flow-paths determined by hydraulic conductivity and sediment permeability appear to play an important role in their study. Similarly, Battin (2000) shows a clear link between microbial activity and streambed hydrodynamics. Nutrient availability that is linked to interstitial flow (Findlay 1995) can also play an important role in higher respiration rates in the flow-through system. Addition of bioavailable organic carbon (acetate) resulted in increased respiration of hyporheic sediments in the Flathead River (Craft et al. 2002). Unfortunately, we did not measure the levels of nutrients during the closed chamber experiment and we cannot confirm this assumption from the results of our study.

The measured heterotrophic respiration of naturally heterogeneous sediments was $1.27 \pm 0.03 \mathrm{mg} \mathrm{O}_{2} \mathrm{dm}^{-3} \mathrm{~h}^{-1}$ or $3.05 \pm 0.07 \mathrm{~g} \mathrm{O}_{2} \mathrm{~m}^{-2}$ day ${ }^{-1}$ in the flow-through system and was within the range of previously measured rates from different studies applying the comparable methodology (i.e. flow-through chambers measuring oxygen consumption within the sediments). For example, respiration rates ranged between 0.01 and $0.33 \mathrm{mg} \mathrm{O}_{2} \mathrm{dm}^{-3} \mathrm{~h}^{-1}$ in sediments (8-12-mm fraction) from the hyporheic and phreatic sites along the Flathead River, USA (6 m deep) (Craft et al. 2002); were $0.13 \mathrm{mg} \mathrm{O}_{2} \mathrm{dm}^{-3} \mathrm{~h}^{-1}$ in the filtering columns containing heterotrophic bacteria from the River Rhone, France (MermilodBlondin et al. 2005); ranged between 0.1 and $1.7 \mathrm{mg} \mathrm{O}$ $\mathrm{dm}^{-3} \mathrm{~h}^{-1}$ in the sand and fine gravel shallow hyporheic sediments from Sycamore Creek, USA (Jones et al. 1995) and between 2 and $6.8 \mathrm{mg} \mathrm{O}_{2} \mathrm{dm}^{-3} \mathrm{~h}^{-1}$ in the shallow hyporheic zone of several mid-order Michigan sand-gravel rivers (Uzarski et al. 2004). From these results, it is clear that respiration decreases with depth and varies over the seasons and between river systems. This is probably due to differences in temperatures, nutrient availability and hydromorphology (sediment composition, direction and the rate of interstitial flow (Jones et al. 1995; Uzarski et al. 2004; Battin 2000).

The observed increase in nitrates and decrease in ammonium in the outflow water indicates that aerobic processes prevail in the incubated sediments, which is also shown by the relatively high oxygen concentrations in the outflow water $\left(>7 \mathrm{mg} \mathrm{L}^{-1}\right)$. Similarly, Ruegg et al. (2015) observed a linear decrease in ammonium concentrations
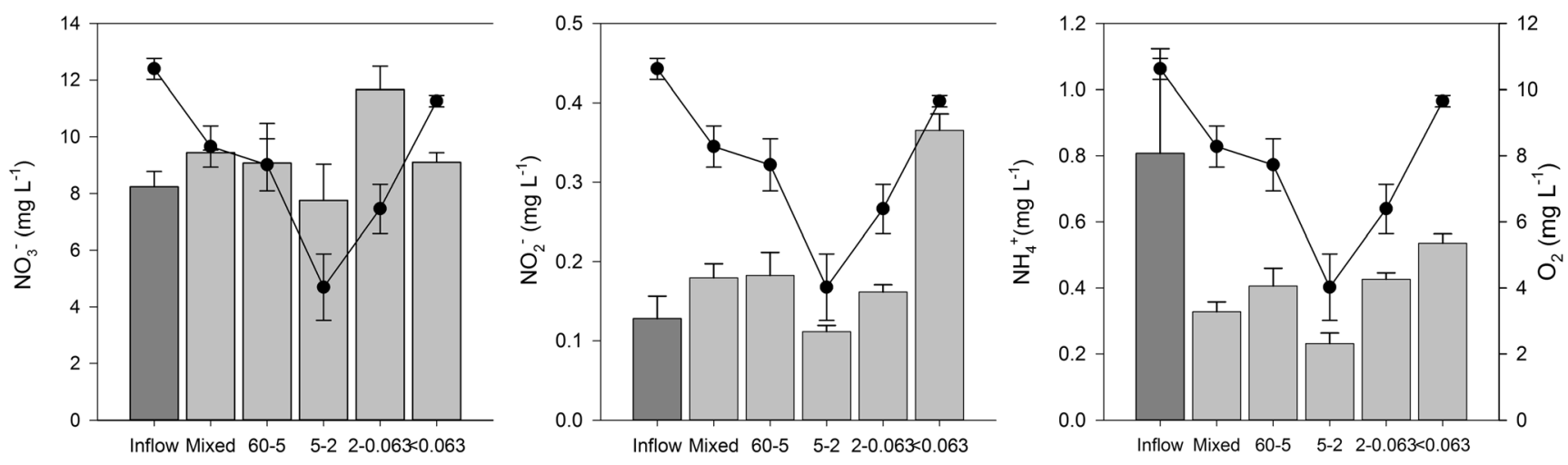

Fig. 6 Nitrate, nitrite and ammonium concentrations measured in the water entering the flow-through system (inflow) and in the water at the outflow. The columns represent the measurements during incubation of mixed (natural) and sieved riverbed sediments. The line represents the oxygen concentrations at inflow and outflow 
Table 1 Estimated mean $( \pm \mathrm{SD})$ carbon fluxes for natural heterogeneous sediment and single sediment fractions from Kamniška Bistrica River sampled in spring 2015

\begin{tabular}{lll}
\hline & $\mathrm{mg} \mathrm{C} \mathrm{dm}^{-3} \mathrm{~h}^{-1}$ & $\mathrm{mg} \mathrm{C} \mathrm{m}{ }^{2}$ day \\
\hline $\begin{array}{l}\text { Natural sediment } \\
\text { Sediment fractions }\end{array}$ & $0.41 \pm 0.09$ & $97.3 \pm 21.7$ \\
$60-5 \mathrm{~mm}$ & $0.09 \pm 0.03$ & $20.5 \pm 6.3$ \\
$5-2 \mathrm{~mm}$ & $0.94 \pm 0.10$ & $226.1 \pm 22.8$ \\
$2-0.063 \mathrm{~mm}$ & $1.53 \pm 0.26$ & $368.4 \pm 61.7$ \\
$<0.063 \mathrm{~mm}$ & $16.27 \pm 7.33$ & $3904 \pm 1759$ \\
\hline
\end{tabular}

in the closed chamber, where during the first $2 \mathrm{~h}$ of incubation, the concentration decreased by $30 \%$. This is indicative of nitrification processes. In anaerobic or low oxygen environments, biogeochemical processes shift towards denitrification, where the levels of nitrate decrease and ammonium increase. For example, Nogaro et al. (2007) detected anaerobic denitrification processes in the presence of oxygen concentrations as low as $0.25 \mathrm{mg} \mathrm{L}^{-1}$ in the slow infiltration columns. Pallud et al. (2007), looking at the influence of flow rates on nitrate and nitrite consumption in brackish and freshwater sediments using flow-through sediment incubators, revealed that during decreased flow rates and increased water residence time in the incubator results in an increase in nitrate consumption. These results reveal the influence of redox conditions, which are related to hydrology, on the biogeochemical processes in riverbed sediments.

Sediment composition is one of the most important physical parameters underlying the hydromorphological characteristics of freshwater ecosystems determining the ecosystemlevel processes such as primary and secondary production and decomposition. However, empirical studies that demonstrate this assumption are rare. For example, Hargrave
(1969) found an inverse relationship between particle size and oxygen consumption, which is a measure of microbial respiration, while Cardinale et al. (2002) were able to show a clear link between the level of sediment heterogeneity and stream metabolism. Here, the respiration rates of the stream biofilm were on average $65 \%$ greater in a stream riffle with high substrate heterogeneity vs. low heterogeneity riffles, which is likely due to changing hydrological patterns. Marxsen (2001) was able to show that only $17 \%$ of the total biofilm carbon production is attributed to coarse sediments in the studied stream while the remainder is produced on sandy sediments. Interestingly, Santmire and Leff (2006) found no difference in the bacterial community composition among different sediment fractions indicating that in their case, functioning rather than structure underlies these differences. Also, Thomaz et al. (2001) found no correlation between particle size and microbial respiration in waterbodies of the upper Paraná River floodplain but did recognize the phosphorus contents as important variable. In contrast to our study, their study compared fine sediments, with four sediment classes of sizes below $0.070 \mathrm{~mm}$.

Our study clearly demonstrates the effect of sediment grain size on metabolic processes and biogeochemical transformations. The heterotrophic respiration recalculated per dry weight of the measured sediment was the highest for the finest sediment fraction $(<0.063 \mathrm{~mm})$, while the ammonium and oxygen uptake was the most intensive for sediments with sizes between 2 and $5 \mathrm{~mm}$. The larger area-to-volume ratio of smaller particles, and hence the larger area available for microbial colonization, is one possible explanations for the high respiration observed in the finest sediments (Baker et al., 2000). Moreover, the amounts of particulate organic matter (POM) were two to three times higher in the smallest fractions as measured in previous unpublished experiments on the investigated sediments. Hence, respiration and mineralization processes in sediments are linked to the amount of POM
Fig. 7 Composition of riverbed sediments and contribution of each size class to the total respiration

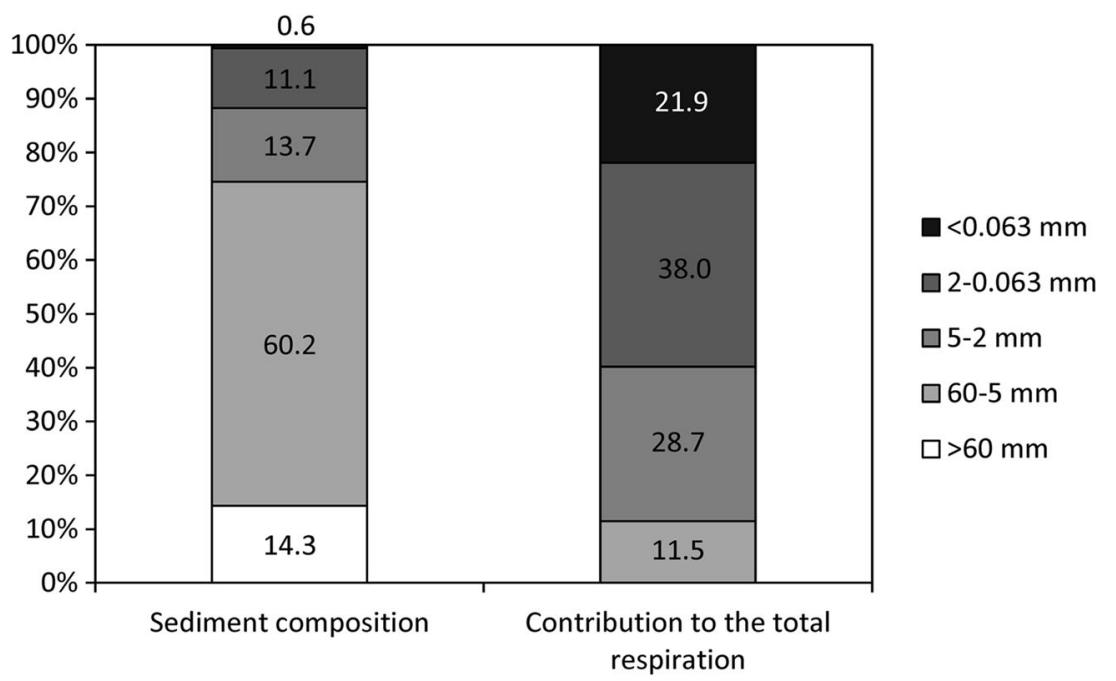


(Nogaro et al. 2007). Interestingly, the most intense nutrient transformations took place on the medium sediment fractions (2-5 mm), indicating a trade-off between the surface area available for biofilm formation and interstitial permeability that determines the hyporheic respiration.

\section{Conclusions}

The study demonstrated the applicability of a newly designed flow-through system for laboratory experiments on a small scale, where mimicking realistic interstitial flow conditions enables the design of different experiments related to hyporheic zone processes. It also confirmed that previously known observations that closed respiration chambers underestimate heterotrophic respiration and that substrate composition has a substantial effect on respiration rate. This study is also important in terms of river basin management since it shows that increasing sedimentation strongly affects respiration processes; fine sediments contribute most to ecosystem respiration but excessive sedimentation may clog the interstices, creating anoxic environments and limiting heterotrophic respiration.

Acknowledgements The authors thank Andreja Jerebic for the water chemistry analyses and Johanna Robinson for graphical support. We thank Drago Brodnik for the prototype design and construction, and Anton Brancelj for the insightful suggestions during the development of the flow-through chamber system. The study was partly funded by the Slovenian research agency (ARRS) (L2-6778; P1-0255) and partly by the European Communities Seventh Framework Program Funding under Grant agreement no. 603629-ENV-2013-6.2.1-Globaqua.

Open Access This article is distributed under the terms of the Creative Commons Attribution 4.0 International License (http:// creativecommons.org/licenses/by/4.0/), which permits unrestricted use, distribution, and reproduction in any medium, provided you give appropriate credit to the original author(s) and the source, provide a link to the Creative Commons license, and indicate if changes were made.

\section{References}

Baker MA, Dahm CN, Valett HM (2000) Anoxia, anaerobic metabolism, and biogeochemistry of the stream-water-ground-water interface. In: Jones JB, Mulholland PJ (eds) Streams and ground waters. Academic Press, San Diego, pp. 259-283

Battin TJ (2000) Hydrodynamics is a major determinant of streambed biofilm activity: from the sediment to the reach scale. Limnol Oceanograp 45:1308-1319

Battin TJ, Besemer K, Bengtsson MM, Romani AM, Packmann AI (2016) The ecology and biogeochemistry of stream biofilms. Nat Rev Micro 14:251-263

Bodmer P, Freimann R, Fumetti SV, Robinson CT, Doering M (2016) Spatio-temporal relationships between floodplain structure and microbial function. Aquat Sci 78:241-254
Boulton AJ, Findlay S, Marmonier P, Stanley EH, Valett HM (1998) The functional significance of the hyporheic zone in streams and rivers. Annu Rev Ecol Syst 29:59-81

Bowman GT, Delfino JJ (1980) Sediment oxygen demand techniques: a review and comparison of laboratory and in situ systems. Water Res $14: 491-499$

Boyd CE (1995) Soil organic matter, anaerobic respiration, and oxidation-reduction. In: Boyd CE (ed) Bottom soils, sediment, and pond aquaculture. Springer US, Boston, pp. 194-218

Cardinale BJ, Palmer MA, Swan CM, Brooks S, Poff NL (2002) The influence of substrate heterogeneity on biofilm metabolism in a stream ecosystem. Ecology 83:412-422

Commission of the European Communities (2000) Directive 2000/60/EC of the European Parliament and of the Council of 23 October 2000 establishing a framework for Community action in the field of water policy. The Official Journal (OJ L 327) on 22 December 2000

Craft JA, Stanford JA, Pusch M (2002) Microbial respiration within a floodplain aquifer of a large gravel-bed river. Freshwat Biol 47:251-261

Crawford JT, Stanley EH (2016) Controls on methane concentrations and fluxes in streams draining human-dominated landscapes. Ecol Appl 26:1581-1591

Dilly O (2001) Microbial respiratory quotient during basal metabolism and after glucose amendment in soils and litter. Soil Biol Biochem 33:117-127

Doering M, Uehlinger U, Ackermann T, Woodtli M, Tockner K (2011) Spatiotemporal heterogeneity of soil and sediment respiration in a river-floodplain mosaic (Tagliamento, NE Italy). Freshwat Biol 56: 1297-1311

Elosegi A, Diez J, Mutz M (2010) Effects of hydromorphological integrity on biodiversity and functioning of river ecosystems. Hydrobiol 215:199-215

Findlay S (1995) Importance of surface-subsurface exchange in stream ecosystems: the hyporheic zone. Limnol Oceanogr 40:159-164

Foulquier A, Simon L, Gilbert F, Fourel F, Malard F, Mermillod-Blondin F (2010) Relative influences of DOC flux and subterranean fauna on microbial abundance and activity in aquifer sediments: new insights from 13C-tracer experiments. Freshwat Biol 55:1560-1576

Griebler C (1996) Some applications for the DMSO-reduction method as a new tool to determine the microbial activity in water-saturated sediments. Arch Hydrobiol Suppl 113:405-410

Grimm NB, Fisher SG (1984) Exchange between interstitial and surface water: implications for stream metabolism and nutrient cycling. Hydrobiol 111:219-228

Hancock PJ (2002) Human impacts on the stream-groundwater exchange zone. Environ Manag 29:763-781

Hargrave B (1969) Epibenthic algal production and community respiration in sediments of Marion lake. J Fish Res Board Can 26:2000-2026

Jeppesen E (1982) Diurnal variation in the oxygen uptake of river sediments in vitro by use of continuous flow-through systems. In: Sly PG (ed) Sediment/freshwater interaction. Springer, Netherlands, pp. 189-195

Jones JB, Fischer SG, Grimm NB (1995) Vertical hydrologic exchange and ecosystem metabolism in a Sonoran desert stream. Ecology 76: 942-952

Lampert W (1984) The measurements of respiration. In: Downing JA, Rigler FH (eds) A manual on methods for the assessment of secondary productivity in fresh water. Blackwell Scientific Publications, Oxford, pp. 413-468

Marxsen J (2001) Bacterial production in different streambed habitats of an upland stream: sandy versus coarse gravelly sediments. Arch Hydrobiol 152:543-565

Mermillod-Blondin F, Cruezé des Chatelliers M, Marmonier P, DoleOlivier M-J (2000) Distribution of solutes, microbes and invertebrates in river sediments along a riffle-pool-riffle sequence. Freshwat Biol 44:255-269

Mermillod-Blondin F, Mauclaire L, Montuelle B (2005) Use of slow filtration columns to assess oxygen respiration, consumption of 
dissolved organic carbon, nitrogen transformations, and microbial parameters in hyporheic sediments. Water Res 39:1687-1698

Mermillod-Blondin F, Winiarski T, Foulquier A, Perrissin A, Marmonier P (2014) Links between sediment structures and ecological processes in the hyporheic zone: ground-penetrating radar as a non-invasive tool to detect subsurface biologically active zones. Ecohydrology 8: 626-641

Naegeli MW, Uehlinger U (1997) Contribution of the hyporheic zone to ecosystem metabolism in a prealpine gravel-bed river. J N Am Benthol Soc 16:794-804

Nogaro G, Mermillod-Blondin F, Montuelle B, Boisson J-C, Bedell J-P, Ohannessian A, Volat B, Gibert J (2007) Influence of a stormwater sediment deposit on microbial and biogeochemical processes in infiltration porous media. Sci Total Environ 377:334-348

Orghidan T (1955) Un nouveau domaine de vie souterraine aquatique: le biotope hyporhéique. Bull Biol Acad R.P. Romania. 7:657-676

Pallud C, Meile C, Laverman AM, Abell J, Van Cappellen P (2007) The use of flow-through sediment reactors in biogeochemical kinetics: methodology and examples of applications. Mar Chem 106:256-271

Prahl C, Jeppesen E, Sand-Jensen K, Moth-Iversen T (1991) A continuous-flow system for measuring in vitro oxygen and nitrogen metabolism in separated stream communities. Freshwat Biol 26: 495-506

Pusch M, Schwoerbel J (1994) Community respiration in hyporheic sediments of a mountain stream (Steina, Black Forest). Arch Hydrobiol 130:35-52

Pusch M, Fiebig D, Bretter I, Eisenmann H, Ellis BK, Kaplan LA, Lock MA, Naegli MW, Traunspurger W (1998) The role of microorganisms in the ecological connectivity of running waters. Freshwat Biol 40:453-495

Ruegg J, Brant JD, Larson DM, Trentman MT, Dodds WK (2015) A portable, modular, self-contained recirculating chamber to measure benthic processes under controlled water velocity. Freshwat Sci 34: 831-844
Santmire JA, Leff LG (2006) The influence of stream sediment particle size on bacterial abundance and community composition. Aquat Ecol 41:153-160

Simčič T, Mori N (2007) Intensity of mineralization in the hyporheic zone of the prealpine river Baca (West Slovenia). Hydrobiol 586:221-234

Simčič T, Mori N, Hossli C, Robinson CT, Doering M (2015) The response in floodplain respiration of an Alpine river to experimental inundation under different temperature regimes. Hydrol Process 29: $5438-5450$

Thomaz SM, Pereira G, Pagioro TA (2001) Microbial respiration and chemical composition of different sediment fractions in waterbodies of the upper Paraná River floodplain. Brazil Rev Brasil Biol 61:277-286

Uehlinger U, Naegli MW, Fischer SG (2002) A heterotrophic desert stream? The role of sediment stability. West N Am Naturalist 62:466-473

Uzarski DG, Burton TM, Stricker CA (2001) A new chamber design for measuring community metabolism in a Michigan stream. Hydrobiologia 455:137-155

Uzarski DG, Stricker CA, Burton TM, King DK, Steinman AD (2004) The importance of hyporheic sediment respiration in several midorder Michigan rivers: comparison between methods in estimates of lotic metabolism. Hydrobiol 518:47-57

Valett HM, Morrice JA, Dahm CN, Campana ME (1996) Parent lithology, surface-groundwater exchange, and nitrate retention in headwater streams. Limnol Oceanogr 41:333-345

Wagner FH, Bretschko G (2002) Interstitial flow through preferential flow paths in the hyporheic zone of the Oberer Seebach, Austria. Aquat Sci 64:307-316

Yvon-Durocher G, Caffrey JM, Cescatti A, Dossena M, del Giorgio P, Gasol JM, Montoya JM, Pumpanen J, Staehr PA, Trimmer M, Woodward G, Allen AP (2014) Reconciling the temperature dependence of respiration across timescales and ecosystem types. Nature $487: 472-476$ 